\begin{tabular}{c} 
Volume and Issues Obtainable at Center for Sustainability Research and Consultancy \\
Journal of Business and Social Review in Emerging Economies \\
ISSN: 2519-089X \& ISSN (E): 2519-0326 \\
Volume 7: Issue 2 June 2021 \\
CSRட \\
Journal homepage: www.publishing.globalcsrc.org/jbsee \\
\hline
\end{tabular}

\title{
Terrorism as a Major Threat to Societal Peace: The Case of Pakistan
}

*Tahir Ashraf, Assistant Professor, Department of International Relations, Bahauddin Zakariya University, Multan, Pakistan

Bushra Fatima, PhD Scholar, Department of Political Science, University of the Punjab, Lahore, Pakistan

*Corresponding author's email: tahirmian1@bzu.edu.pk

\section{ARTICLE DETAILS \\ History \\ Revised format: May 2021 \\ Available Online: Jun 2021}

Keywords
Terrorism,
Pakistani Society,
Societal Peace,
Counter-Terrorism,
Insecurity

JEL Classification

H80, H89

\begin{abstract}
Purpose: The central objective of this research is to look at causes behind the phenomenon of terrorism faced by Pakistan. In the contemporary era, Pakistan is facing and suffering from the destructive and gravest issue of terrorism. It has become a major problem not only for the federation as well as for the citizens of Pakistan. Terrorism has made the Pakistani society, where people do not feel secure, a society that lacks a responsible system. The factors that caused terrorism are societal despotism, economic inconsistency, political uncertainty, religious dogmatism as well as foreign intervention or international stratagem.
\end{abstract}

Design/Methodology/Approach: Qualitative method has been used in this study. Secondary sources including newspapers and research articles have been used to evaluate reasons as well as the dynamics of the phenomenon of terrorism which has severely damaged social fabric of the Pakistani society.

Findings: The article has evaluated the major causes of multiple societal dimensions of terrorism and found that unsystematic government set-up, non-democratic system, absence of law and order and frustration and collapse of law enforcement organizations, incursion, and ingress of refugees, weaponization as well as talibanization. It has also revealed that role of religious institutions, madrassas and religious sermons delivered on the occasion of daily life religious rituals are major reasons of the extremism prevailing in the Pakistani society.

Implications/Originality/Value: So, it is concluded that the major causes of multiple societal dimensions of terrorism are religious institutions, hate-speeches delivered at different ceremonies of religious and social rituals.

(C) 2021 The authors, under a Creative Commons AttributionNonCommercial 4.0

\footnotetext{
Recommended citation: Ashraf, T. and Fatima, B. (2021). Terrorism as a Major Threat to Societal Peace: The Case of Pakistan. Journal of Business and Social Review in Emerging Economies, 7 (2) 443-452.
} 


\section{Introduction}

Pakistan being an Islamic state and the land of the Muslim majority is on the crossroads through facing and suffering from the bloody attacks of terrorists. Terrorism has seriously caused Pakistani society and has created threatened impacts to destruct the societal peace of Pakistan. One cannot deny the fact that peaceful society in the country does make its citizens live freely and with mental peace rather the terrorist attacks have emerged to spread poison, blood, devastation, destruction, violence, fear, an atmosphere of danger, insecurity, mental stress. Historically, the concept of terrorism is as ancient as human development. To understand and to know about the term terrorism one must know the violence of the time of the French revolution. In traditional times, terrorism indicates in the shape of individuals and tribal disturbance. Afterward, many small states faced up to the terrorist attacks by the larger states. In human history, there are unnumbered wild wars in which billions of humans were exterminated in violent terrorist actions. Unfortunately, such violent actions are still visible to human eyes and humans are badly suffering even in the 21st century. There are multiple examples of human violence in world history either it was seen when Alexander the Great, Hitler of Germany, the Roman warriors, Europeans, and other combatants, fighters murdered a large number of innocent people that have ultimately created destruction in the society. Even there were fights and wars based on religion. Above all, terrorism in the modern era has taken a new form to destruct societal peace either in the case of Iran, Iraq, the Middle East, Kuwait, Africa, the USA, Turkey, or any country of the globe. Even though the cruel acts of terrorism are noticeable and seen all over the globe though Pakistan is going through the brutal acts of terrorism directly and extremely in the form of social trouble and social mess. Due to the outbreaks of terrorism, Pakistan's society is labeled as unrest and violent society, where no building, no footpath, no area is perceived and considered as a peaceful place. In the international community, Pakistan is at the forefront of the war against terrorism and thus the population and the state itself are facing the anger and horror of terrorists. Pakistan being a developing country got independence from the British Empire in 1947. Four provinces of Pakistan namely Punjab, Sindh, Baluchistan, and Khyber Pakhtunkhwa none of them are safe from the bloodshed of terrorist groups.

\section{Terrorism in Pakistani Society}

It is estimated in 2016 the population of Pakistan is 193,368,813. For Pakistan's development and progress, terrorism is the biggest danger. Its origin can be seen since 1979 when there was an attempt to throw out Russia from the territory of Afghanistan. The societal spectrum of Pakistan is considered to be the most peaceful society but due to the invasion of Russians in Afghanistan (a neighboring country), the social setup of Pakistan saw a big hurdle and crush in the economic as well as political systems. On the other side, the militant organizations were motivated by the superpowers of the world to develop Jihad culture in the form of a holy war in Islam to overthrow Russians. In the eighties, the land of Pakistan was considered a fruitful piece of earth for the militants to attract the young generation to overthrow the Russian forces. Perhaps during the ruling era of Zia-ul-Haq (1977-1988) and other ruling groups were enjoying and taking advantage of the ideas of the superpowers of the world, afterward when the removal of the Russians from Afghanistan, all the extremist militants' groups separated and moved in different directions. Later on, the role of the international society takes back the support from the militant organizations and also changed their plan and agenda. These militant groups were very rich and ambitious in money, weapons as well as in terms of religious and political domination in the region to fight against each other. Moreover, during the Afghan war (1979-1989) a large number of arms, weapons, bullets, and missiles were stored in Pakistan that were later on utilized by these militants' groups in extreme tribal and political violence. However, social injustice, political turmoil, economic instability, crimes, corruption giving fuel to different forms of terrorism. Thus, the geopolitical scenario of Pakistan changed with the disintegration of Russia from the international order. Due to this changed scenario, the mud of terrorism strongly grasps and 
speedily spread in Pakistani society. However, the difficulties and problems arise after the 9/11 incident, and in the contemporary era, it has appeared as a major threat for our country.

The increase of political Islam and terrorism in Pakistan has regional, international as well as domestic connotations. Domestically, the increase of political Islam and terrorism in Pakistan has extremely affected the building of state and society of Pakistan (Ahmed, 2007).

Pakistan is playing an effective role to stop militant groups and terrorism that used to increase terrorism acts in Pakistan. The proliferation of terrorism has strengthened the sound of fear and intolerance in the society. Terrorism is one of the social immorality, social wickedness, and social wrongdoing not only in the case of Pakistan but for the whole world to destroy mankind. This is how terrorism takes place in Pakistan and badly, adversely beat the society as a social, economic and political tussle. Hence the social employees being major part and contributors to society to bring social change must work and think on the pattern of how to defeat the fearful and striking effects of terrorism for good social change and development.

Terrorism is a complicated phenomenon that has multiple connotations likely a "creation of violence", "fearful action", "societal disturbance", and a "loss of mankind". Terrorism in Pakistan has cost a big threat and loss of humans. Therefore, for terrorist acts two terminologies come at the forefront is "mala prohibita acts" and "mala in se acts". Prior means crimes that are made illegitimate by law, whereas later means those crimes which are crimes which are immoral. It is a social activity which can be used in the hour of peace and conflict. On the other in defining that what is a terrorist organization, it is an illegal secret organization that usually consists of planners, trainers, and true bombers or actual killers. There are multiple frameworks of a terrorist organization like known social order of command, a horizontal framework is those where leading authorities are unknown or where they do not have any key role, and the terrorists prefer to act alone or lone wolves.

Terrorism is a phenomenon that lacks symmetry warfare. Asymmetric warfare is that warfare where there is a use of unplanned or unforeseeable inhumanity by a weak group meaning by those with a small weaker force in opposition of the stronger one which includes government, military, or society to gain benefit. It is a kind of warfare that is fought between extremely opposite sides. Here the weaker one cannot attack the stronger side in terms of the traditional rules of war reasoning that it cannot attain by adopting such strategies. The main aspect of asymmetric warfare means to have unpredicted and uncommon moves in warfare. This can be related to the aspect of war with no front lines, a war conducted under the umbrella in opposed to the nameless enemy, without knowing that where it would move and how it would conclude?

Some of the analysts describe the common worldwide phenomenon of terrorism in the shape of four phases i.e. the very first phase of terrorism can be seen from the era of late $19^{\text {th }}$ century and $20^{\text {th }}$ early century. Second phase was called as the colonial phase that is compact within the national geographic borderline from the year 1921 till the present day. The third phase called the present move to and fro, launched global terrorism, crossroads national borders, which initiated in the 1960s. For example, 9/11 terrorist attacks explain the fourth phase of terrorism. In this phase, terrorism has reached the international stage. There is a use of any kind of weapons and arms to be used. It is very common saying that terrorism is the war of all against war. In the fourth phase, where terror means destruction in terms of both physically and imaginatively through the largest killings, murders, the frequent availability and uses of weapons of mass destruction, and religious laws for terrorist attacks opposing ordinary citizens.

Its complexity can be seen due to the facts of different factors from internal circumstances to foreign developments. 
The economy, politics, social area, national security, integrity all are negatively affected by terrorism. However, the menace of being labeled as a failed state is not any other problem but only terrorism is the reason. No doubt, this issue cannot be easily resolved with the involvement of a single individual rather it demands a collective honest effort. A motivated and wide-ranging counter-terrorism strategy has become an essential need of time. The political unity and coherence between the institutions is the mandatory move in this respect.

The emergence of terrorism in Pakistan can be seen from the two important incidents, which conduct regression, dogmatism, and consequently terrorism in Pakistan. Prior to 1980s, religion has never been a disputable pitfall in Pakistan. After 1979 Iranian revolution, the sectarian extremists appeared in Pakistan that has modified the essence and significance of sectarian sadism in Pakistan. Other than this, the Soviet invasion of Afghanistan was the most critical incident in terms of extensive belligerence. Major change reshapes the society in Pakistan emerged after the flood of the Soviet-Afghan war. The real damage was uncovered after the Soviet termination from Afghanistan, where occurred weaponization and violence in Pakistan. Perhaps, later on, due to the USA attack on Afghanistan and Pakistan in War on Terror as a confederate, the noise of extremism, militancy, and terrorism fly up. The weight of terrorism has become quite greater due to its diverse nature. There are multiple forms of it, which include, ethnic, sectarian, nationalist separatist, as well as jihadi terrorism.

Since Pakistan's emergence as an independent state, increase of ethnic diversity or form of sectarianism is the most soul-stirring. Due to this factor of ethnicity, the country was divided into parts in 1971. Bombings, fire-raising, physical attacks, damaging of property and even murders have been some facts of that time. Separatist terrorism is one of the other threats to Pakistan. For example, the province of Baluchistan is suffering from the broken guerilla wars. The foreign powers who carry out evil and wicked terrorism acts also resort to target killings to promote their separatist agenda.

Jihad is another category of terrorism that is the most widespread in the present era. This type of terrorism originated when the Soviets invaded Afghanistan in the late 1970s. When later on Soviet termination, this armed brawl changed into a civil war, and afterward, Afghanistan became an upbringing and reproduction land for terrorists. Moreover, after the 9/11 attacks, some of the jihadi groups revolve their guns against Pakistan. The reason of being Pakistan's present situation is going in a critical situation due to multiple causes such as underdevelopment, strategic location, mixed cultures, and religious position of society.

\section{Major Causes of Terrorism}

The major cause is the extensive illiteracy rate in Pakistan. In the literacy rate index, Pakistan ranks $113^{\text {th }}$ among the 120 nations. However, people are unaware of the real teachings of Islam, they are smoothly enraptured by the emotional debates about religious extremists (Sodhar, 2013).

- Lack of justice is the main cause of terrorism in Pakistan where the common people do not get justice being the nationalists they are continuously suffering from the illness of the society either in the form of unequal resource of distribution, limited access to the quality of education, and the most rising is that of those who belong to any elite's authority in the political system would get all the benefits, deficiency in case of health facilities, and nonavailability of basic needs and commodities to the large part of the population. People are not getting their fundamental rights of being human. In Pakistan, the lower depressed class is at the front to be exploited by the terrorists.

- Crash of democracy by military dominions also took part in terms of the spread of terrorism in Pakistan. History tells it was mainly due to the military authorities that indulged Pakistan in this dilemma. For instance, when Zia took a decision to include 
Pakistan in the war against the Soviets in Afghanistan, similarly due to General Pervez Musharraf era when he emphasized in order to put Pakistan on the frontline as an ally of the US in the war against terrorism.

- Poverty and Unemployment are also the cause of terrorism in terms of the major threat to societal peace in Pakistan, when people do not get their essential needs their basic necessities all such issues forced them to go for suicide which is the worst impact on others. As presented by the Sustainable Development Policy Institute, every third Pakistani income is below the poverty line i.e. 58.7 million out of 180 million are existing in creeping poverty. Benazir Income Support Program (BISP) conducted a survey and find that almost $45.7 \%$ population of Pakistan is poor. Such people, grasped in the brutal cycle of poverty, join terrorists for financial benefits (Sodhar,2013).

People in Pakistan on daily basis are dying and want to get rid of life or they opt for suicides either because of poverty, hunger, disease, not getting appropriate jobs or because of the injustice attitudes, they are facing due to the non-attentive attitudes of governmental bodies. In Pakistan, poverty, inequality, unemployment, lack of jobs for qualified people, the fact of discrimination between rich and poor, and low economic conditions are said to be the root causes of terrorism. Because of the poverty factor, people who cannot afford are unable to send their children to institutions and were convinced to send them to madrassas which is a place of no standard and backward place for getting knowledge in the name of Islamic education.

In Pakistani society, everyone is quite aware and it is obvious to say that madrassas are the vital source of militancy. It is not originated from the poor economic background rather the teenagers who belong to poor family backgrounds used to directly join the militant communities in order to improve their living standards. Hence poverty compelled the provision of a big supply of manpower for terrorist organizations.

- The religious intolerance in Pakistan also causes terrorism. The unbearable conflict between Sunni and Shia, which in every province of Pakistan due to these Sunni-Shia extreme issue many mosques have been attacked for which the major threat to societal peace wherein people even do not go for prayers.

- In the Afghan war, where Pakistan's participation has also torture the country with terrorism. Then these militias have become so unchecked that they used to challenge the process of the government in different areas of the country. It is also one of the causes of terrorism in Pakistan, consequently, a high level was given in taking part in war on terror. Pakistan's contribution to the war on terror is considered to be meant as Pakistan's support for the USA, UK, and NATO forces in the war on terror that was basically originated by the USA in finding Usama bin Laden after the horrible incident of $9 / 11$ attacks. By means of the historical notion, Pakistan supported these groups for achieving its goals and objectives in Afghanistan and India, but realistically, Pakistan part in war on terror emerged as a conversion of these groups into anti-Pakistani militants, and they started attacking Pakistan's police, army, infrastructure as well as civilians. As such these anti-Pakistan groups enabled themselves as Tehreek-e-Taliban Pakistan (TTP). Several attacks of a large number of mass destruction such as attacks on Mehran naval base in 2011 and many others social destruction was claimed by this militant organization. Later on, in 2014 joint military organizational forces of Pakistan have joined to start an offensive "Operation Zarb-e-Azb", in opposition to such militant communities.

- Terrorism rise in Pakistan due to its crippled economy. The fluctuated economy has escalated inflation, poverty, and unemployment rate. Pakistan Economy Watch (PEW) conducted a survey, which reveals that nearly 50\% of the Pakistani workforce is unemployed (Sodhar,2013). Miseries and hardships forced people to go for acquiring 
additional approaches of income and terrorists attract such criticized people. Hence such economic weakness enabled business for terrorists quite possible.

- Lack of law implementation is a vital cause of terrorism. In order to define law implementation, it makes sure obedience to state laws and rules and is usually regarded as a society's stately attempt to acquire agreement with the general rules, regulations, and laws of the society. Being a crucial counterterrorism tool, law implementation has a lot to be concerned with terrorism and it is a big source of akin response in terms of the acts of terrorism. But unluckily the law enforcement situation is depressing. It is observed that the ineffectiveness of law enforcement has allowed the open field for the terrorist's activities to be carried out.

The legislation regarding antiterrorism has many flaws. From the security perspective, there are deficiencies in terms of Pakistan's anti-terrorism act. For example, many holds-up terrorists are released without any trial and judicial proceedings as their imprisonment end without any measures and actions. There is a lack of a systematic mechanism in order to gather and protect genuine proof in front of the court, a very discouraging police system, non-availability of highsecurity prisons for terrorists' suspicions and distrusts, deficiency in terms of the security for the judges, prosecutors, and spectators. Deficiency lies in checking mechanisms over religious madrassas and mosques.

- External Interference is also the utmost cause of terrorism in Pakistan. It is quite observable that foreign intelligence agencies are vastly present in the state, also they are encouraging and supporting financially as well as giving them training to the terrorists in anti-state activities. The foreign involvement has had a negative impact on the part of the media's role in Pakistan. The foreign agencies most popular are CIA, RAW, and Mossad, i.e. USA, India, and Israel respectively have involvement in terrorist activities and playing terrorists games in Pakistan. The media also reported that there is a vast existence of Blackwater involvement in terrorist attempts in the country.

- One of the most influential causes of terrorism is that of oppression. This can be the outcome of the group's representation of governments and their actors as oppressive and harsh. Then for such things, terrorism provides food to lessen the power. In autocratic societies, where there are military-occupied areas or also in the international arena, by means of the political image is limited, those groups which are against the current state matters often hold in terrorism as a main aspect of the expression and not as a last center or destination. On the part of the nationalist-separatist movements like Hamas, terrorists usually appeal to the unjust action by governments that deny them dignity, recognition, security, and liberty as the main cause for joining terrorist communities. In the case of Pakistan, oppression of Muslims encourages terrorism.

For example, in the case of the Shia-Sunni conflict, where one sees the oppression and discrimination among the citizens. Many terrorists' attacks on Sunni Muslims and Shia Muslims. This kind of religious discrimination highly impacts societal norms and values in a harsh way. Today in Muslim countries, Sharia is based on the findings of ijtihad (the process of making a legal decision by an independent explanation of legal sources i.e. Quran and Sunnah) and taqlid which means "to follow" of those discoveries by the later scholars of Islam in the wake of already laying social duties. With hour, people who are dominant in league with the priesthood have used this twisted version of Sharia in order to reach their personal and political conclusions. Now in the present scenario, there is a need to restore the original Islamic teachings only then the Muslims can get rid of the terrorism and intolerance in the country.

- Mortality Salience meant for when the individual got the awareness of his or her death is inescapable. This aspect is related to the terror management theory. In Pakistan, the 
sudden death of Qandeel Baloch, where the role of media is presenting one in reporting and through news and awkward impact in the societal setup. For such media must perform its duties carefully. Similarly, many leaders were being murdered and killed due to the political issues among the political parties at the state level. All these signals the acts of terrorism.

- Pakistan being a multi-national and multi-lingual country. Racism in Pakistan does exist although Pakistan came into being in the name of Islamic teachings. As in Islam no matter which color, race, or ethnicity he or she belongs to. People are fighting in the country on the basis of racial discrimination that is one of the big sources of origin of terrorist acts.

- Egoism and Arrogance are the key issues of individual psychology that bring arrogance, prejudices, and impatience attitudes in society. Such actions by the people make society a difficult place. For example, every day such cases appeared that in rural as well as in urban areas of Pakistan, where people are going for suicides or they are killing others either due to personal issues or due to the issue of properties, land, marriage, or domestic matters which increases the notion of frustration among public.

- Interest and Agitation Seeking is another factor that initiates the path of terrorism. Agitation seeking means the sudden inborn risk and animation which is provided by the terrorist career. It is being noticed that interest and agitation seeking are more prone towards joining the terrorist organizations for creating violence. Some of the terrorists are also labeled as the stress seekers by which they do not have control over their emotions and their rude behaviors escalating in the society shows that are more concerned about their personal reward and feel powerful by creating terror and violence at the state-level.

- Financial gain causes terrorism among the states. If one country is financially going at a high level, then chances of terrorist acts are also raised to destroy the economy and social sectors of the country. In case of China-Pakistan- Economic Corridor (CPEC) that is building for the development of the economy and financial needs of the states but if any foreign actor involves like India, the hostile state for Pakistan, can cause a threatening image for the country.

- Hatred for the international economic hegemony is one of the main variables that draw terrorists on the journey to make an unbearable situation of the country. The countries which are economically stable, for such cases the wrong doers supported to escalate terrorism. In case of Al-Qaeda where Pakistan and Afghanistan do matter. Many terrorists regard with distrust and hatred the World Trade Organization (WTO). It is described by the Bureau of Economic Analysis, that the September 11, 2001 attacks shattered \$16 billions of private and governmental property, which includes frameworks, computer apparatus, and software.

- Network of Communication denotes the rising actions of the terrorist groups and terrorist organizations, where through the channels of communication they reached their targeting place. For example, many incidents do see by the nations of Pakistan that sometimes do blame the neighboring countries likely Afghanistan and India for such actions same is the case if any terrible acts were held there, they also make blamed Pakistan, which ultimately leads to the sense of the negative image of hatred among each other.

For any viable state, terrorism emerged as a giant threat. It leads threat to the democratic system. Pakistan has had only a vibrating democracy. If the environment of insecurity wins, democracy would never prosper, and due to which the people would lose trust in the democratic system. The sovereignty of Pakistan is also threatened by terrorism. These terrorist groups have had made the entrance of drone attacks which occurs as a serious and swear issue to the sovereignty of the country. From the economic perspective, these terrorists' attempts in Pakistan have raised capital and investors. The capitalists are unwilling to put money into because of the unsystematic law and order in the country. Terrorism also affects the tourism industrial sector in Pakistan. Due to these threatening evils the possibility of good governance also in menace. The governmental 
administrator finds difficulties and unlucky to improve the law and order in the state. National security is endangered by the crisis situation.

Pakistan is divided into small sub-nations struggling and fighting for their existence and independent identity. However, terrorism is a major threat to sovereignty, democracy, governance, to its journey towards progress and prosperity, to national security, to national integrity, and to its economy all these when comes together formed a societal dimension. Terrorism is one type of politically-motivated violence, it is a sensitive and contentious issue which creates controversies all over the world (Ahmad, 2010). Thus all these including crime and corruption causes terrorism to be emerged and give chance to these groups to foster such dangerous actions in the state. Pakistan is a society with mixed identities, by means of provincial governmental identities, along with the ideological recognition, such as Wahhabi, Deobandi, Barelvi, and many others. The social abilities of Pakistan and state policies of Pakistan are distinctive. There is an ongoing struggle between the non-combatants in order to get controlled the state and those in uniform challenging the civilians the right to get control over the rules of the state, such break-up must be taken into consideration when we are going to map up the Pakistani surroundings of terrorism. Most of the time, what happens is that people used to blame others for example the foreign intelligence agencies for damaging Pakistan, although problems and issues lies within the state. Terror in Pakistan is based on a bloodthirsty brand of religion, religious beliefs, and by the state. Sadly, there is a lack of good governance, dishonest and double-dealing rulers of civil and military, inclusive of judicial setup. Irrational and unjustified security is present in the country, which lacks public support. Due to the above-mentioned disasters, there lies a conflicting situation between the state and the society. Thus, the social problems of Pakistan are illiteracy, poverty, unemployment, terrorism, food and water crises, population growth, corruption, internal and external immigration, poor health facilities, discrimination of gender, infrastructure issue, insufficient energy and gas sector, disloyal leaders, democracy in the shape of dictatorship all these symbolize the major threat to societal peace.

\section{Conclusion}

Pakistan is facing terrorism from internal or domestic sides and also from external hands. By means of socio-economic problems in Pakistan, there are illiteracy, injustice, poverty, unemployment, as well as dissatisfaction. The political causes of terrorism in Pakistan include unsystematic government set-up, non-democratic system, absence of law and order and frustration and collapse of law enforcement organizations, incursion, and ingress of refugees, weaponization as well as talibanization. In order to view the religion-based causes, it has the major role of religious institutions, madrassas, and religious extremism. The rays of terrorism can be boosted up due to the ignorance and neglecting attitudes of the governmental sectors. However, Pakistan has certain social, political, economic, and religious facts due to which the terrorists' attacks are day by day increasing and for these citizens of Pakistan can well act by performing their effective role in defeating this horrible act by their wise actions, by informing and reporting to the bureaucratic sources for the immediate response to defeat the acts of terrorism.

For this, the most crucial is that the government of Pakistan has to take in the prior way that to provide their citizens' full security so that the people of the country could easily and safely report the information. For this the support of government or state and people is essential that must be preplanned, must be efficient and actively performed their duties and loyal to their own state and their own people of the country. Perhaps in defeating terrorism, the role of citizens does matter in a sense that they should have that much capability, knowledge, and rational attitude and the rational sense that no other individual or any organization could be deceived, in case if deceived would then be a source of destruction in the whole country. In the present scenario, terrorists have not spared any public places, hotels, and restaurants, educational institutions, parks, shopping 
malls, stadiums, airports, mosques, bazaars or markets, and even hospitals. For all this to prevent defeat counter actions and the role of military agencies and citizens does matter. Defeating terrorism means to remove the destructive nature of the world, defeating terrorism also highlights the aspect to come up with the world so-called peaceful environment for everyone, a kind of peace-loving society where every individual has the right to live freely but under the rules and laws of the state and the citizens' minds must be accordingly the way they are living in a secure society.

\section{References}

Ahmed, D. (2015). Heroin and Extremism in Pakistan. Retrieved from http://foreignpolicy.com/2015/08/17/heroin-and-jihad-in-pakistan/

Ahmad,I. (2010). Pakistan's Responses To Terrorism: Need For Conceptual Framework, Understanding the Terrorist Threat: Defining Terrorism in Pakistani Context. Retrieved from http://www.ishtiaqahmad.com/downloads/terrorism_workshop.pdf

Ahmad. I. (2012). State-Sponsored Terrorism. Retrieved from

http://pakistansocietyofvictimology.org/Userfiles/State\%20Sponsored\%20Terrorism,\%20Ishtiaq \%20Ahmad.pdf

Ahmed, N. (2007). State, Society and Terrorism: A Case Study Of Pakistan After September 11. Retrieved from http://eprints.hec.gov.pk/2554/1/2511.htm

Ammara, F. S. (2015). Media's Role in Bringing a Social Change in Pakistan. Retrieved from http://www.voiceofjournalists.com/medias-role-in-bringing-a-social-change-in-pakistan/

Ammara, F. S. (2016). Devastation of Culture Through Media. Retrieved from http://www.voiceofjournalists.com/devastation-of-culture-through-media/

Ashraf, M. T. (2009). Terrorism in Pakistan: Emerging Trends. Retrieved from

http://www.grandestrategy.com/2009/03/terrorism-in-pakistan-emerging-trends.html

Bukhari, S.(2011). Religious Extremism in Pakistan: A Rude Awakening. Retrieved from http://www.pakistananalysis.com/en/analysis/international/item/240-religious-extremismin-pakistan-a-rude-awakening.html

Chughtai, W. M. (2013). The Impact of Rising Terrorism and Military Operations on Socio Economic Culture of Federally Administered Tribal Areas (FATA) of Pakistan. Retrieved from http://frc.com.pk/wp-content/uploads/2013/07/2.pdf

Daraz, U. \& Naz, A. (2012). Sociological Analysis of Terrorism in Pakistan. Vol.3 No.1 Retrieved from http://www.savap.org.pk/journals/ARInt./Vol.3(1)/2012(3.1-25).pdf

Dijk, V. A. T. (1995). Power and the News Media. Retrieved from http://www.discourses.org/OldArticles/Power\%20and\%20the\%20news\%20media.pdf

Ebadi, Y. (2014). State-Sponsored Terrorism in Pakistan. Retrieved from

https://russia-eastern-republic.com/2014/08/05/state-sponsored-terrorism-in-pakistan/

Geugies, J. C. (2007). The Origins of Terrorism: a comparison between the international antiterrorism strategies of the USA and the Netherlands. Retrieved from http://essay.utwente.nl/58007/1/scriptie_Geugies.pdf

Grothaus, N. (2011), "Types Of Terrorism" Retrieved from http://webcache.googleusercontent.com/search?q=cache:http://handofreason.com/2011/fe atured/types-of-terrorism

Haider,S., Heredero, P. De. C., Ahmed, M. \& Dustageer, S. (2015). “Identifying Causes of Terrorism in Pakistan. from http://www.qurtuba.edu.pk/thedialogue/The\%20Dialogue/10_3/Dialogue_July_Septembe r2015_220-236.pdf

Haq,I. \& Bukhari, H. (2015). Menace of narco-terrorism. Retrieved from http://www.brecorder.com/pages/article/1199732/2015-06-26/menace-of-narcoterrorism.html

Hussain, E. S. (2010). Terrorism In Pakistan: Incident Patterns, Terrorists' Characteristics, and the Impact of Terrorist Arrests on Terrorism. Retrieved from 
http://repository.upenn.edu/cgi/viewcontent.cgi?article=1163\&context=edissertations

Jabbar, J. (2016). Role of Pakistani Media in Pakistan-India Relations. Retrieved from http://www.pildat.org/Publications/publication/FP/RoleofPakistaniMediainPakistanIndiaRelations_BackgroundPaper.pdf

Jan, M. (2009). Political Terrorism under the Flag of Media. Retrieved from http://pu.edu.pk/images/journal/csas/Currentissue/Final\%20Paper\%203.pdf

Khan,W. (2013). Essay: Terrorism in Pakistan. Retrieved from

http://wajahateducation.blogspot.com/2013/02/essay-terrorism-in-pakistan.html

Livesey, C. (2011). The Mass Media Defining the Mass Media. Retrieved from

http://www.sociology.org.uk/media_defined.pdf

Lumbaca, S., Gray, H. D. (2011). The Media as an Enabler for Acts of Terrorism. Retrieved from http://globalsecuritystudies.com/Media.pdf

Mannik, E. (2011). Terrorism: Its Past, Present and Future Prospects. Retrieved from http://www.ksk.edu.ee/wp-content/uploads/2011/03/KVUOA_Toimetised_12M\%C3\%A4nnik.pdf

Primoratz, I. (2003). State Terrorism and Counterterrorism. Retrieved from http://victims.org.uk/s08zhk/pdfs/counter/statesponsorship.pdf

Rana, A. M. (2010). Litterateurs' Response to Extremism in Pakistan. Retrieved from http://san-pips.com/download.php?f=120.pdf

Riaz, S. (2008). Government Influence on Print Media Content in Pakistan :Pakistani Journalists' Perspective. Retrieved from http://www.aiou.edu.pk/gmj/artical5.asp

Sabir, M. (2007). Terrorism a Socio-Economic and Political Phenomenon with Special Reference to Pakistan. Retrieved from http://biztek.edu.pk/qec/jbs/3.1/4.\%20Terrorism\%20a\%20Socio-

Economic\%20and\%20Political\%20Phenomenon\%20with\%20Special\%20Reference\%20t o\%20Pakistan.pdf

Shah, N. M. (2014). Evolution of Sectarianism in Pakistan: A Threat to the State and Society. Retrieved from http://pu.edu.pk/images/journal/csas/PDF/7._Evolution_of_sectarianism_v29_no2_2014.p $\underline{\mathrm{df}}$

Singh,G. \& Grewal,S. D.(2016). Drugs and Terrorism Are Ruining Punjab. Retrieved from https://www.sikhnet.com/news/drugs-and-terrorism-are-ruining-punjab

Sodhar, A. I. (2013). Terrorism The Biggest Threat to Pakistan. Retrieved from http://theallpapers.com/papers/CSS/English/Complete\%20Topic\%20Base\%20Essays/Ess ay---Terrorism\%20The\%20Biggest\%20Threat\%20to\%20Pakistan.pdf

Tisselli, G. (2013). Terrorism in Pakistan. Retrieved from http://www.academia.edu/10831258/Terrorism_in_Pakistan

Usmani, F. (2016). Pakistani Media and Terrorism. Retrieved from http://blogs.arynews.tv/pakistani-media-and-terrorism/

Zahid,I. (2016). Challenges of cyber terrorism. Retrieved from http://pakobserver.net/challenges-of-cyber-terrorism/ 